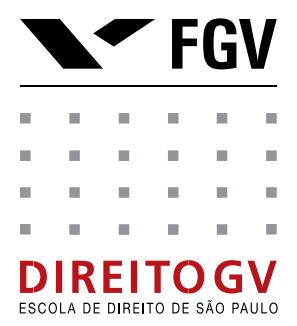

São Paulo Law School of Fundação Getulio Vargas - DIREITO GV

Research Paper Series - Legal Studies

Paper n. 72

\title{
Citizens vs. Banks \\ Institutional Drivers of Financial Market Litigiousness in Brazil
}

\author{
Bruno Meyerhof Salama ${ }^{1}$
}

São Paulo Law School of Fundação Getulio Vargas (DIREITO GV)

Thiago Jabor Pinheiro ${ }^{2}$

Mattos Muriel Kestener Advogados, São Paulo, Brazil

August 2013

This paper can be downloaded without charge from DIREITO GV Working Papers at: http://direitogv.fgv.br/publicacoes/working-papers and at the Social Science Research Network (SSRN) electronic library at: http://www.ssrn.com/link/Direito-GV-LEG.html.

Please do not quote without author's permission.

1 Professor of Law, JSD, LLM, UC Berkeley, School of Law.

2 Associate Mattos Muriel Kestener Advogados, São Paulo, Brazil. 


\begin{abstract}
This article analyzes the institutional drivers of Brazil's alarmingly high levels of litigation between clients and financial institutions. Most of the policy oriented literature that explores that phenomenon discusses the impacts of a perceived debtor-friendly bias of Brazilian courts on generating feedback loops of litigation that further increases interest rates and creates adverse selection within the pool of potential debtors. This literature therefore addresses the way courts behave once disputes reach their doorstep; conversely, we take a step back to understand the underlying reasons for why such a large number of disputes end up in courts in the first place. We accordingly attribute endemic litigation in Brazilian financial markets to a framework of political, economic and legal institutions and circumstances, which this article aims to unbound and explain.
\end{abstract}

Keywords: litigation, regulation, institutions, credit markets, courts.

JEL Classification: K23 


\section{Contents}

1 Introduction

2 Inflation as the Root of All Evils: Monetary Disorder and the Institutional

Letdown within the Brazilian Central Bank 8

2.1 BCB's Path to Becoming a Monetary Authority (1964 - 1986) 9

2.2 Consolidating Monetary and Regulatory Authority (1986 - 1999) 12

2.3 Incomplete Normalization and Institutional Limitations (1999 - Present) 14

3 Explanatory Factors of Credit Litigiousness in Brazil 18

3.1 Overcoming the Conventional Wisdom on the Role of Courts in Brazilian

Financial Markets 18

3.2 Economic Aspects 21

3.2.1 Economic Plans: Learning to Expect the Unexpected 22

3.2.2 Structural Challenges and Macroeconomic Shocks:

Stability, Ma Non Troppo 23

3.3 Political Aspects 25

3.3.1 The Centrality of Courts in the Post-1988 Political

Arrangement in Brazil 26

3.3.2 Opaque Regulatory Process 26

3.3.3 Consumption-Driven Social Inclusion Strategy 28

3.4 Legal Aspects 29

3.4.1 Constitutionalism and Clashing Legal Cultures in

Financial Regulation 29

3.4.2 Judicial Independence and Review Standards 33

3.4.3 Legal Enforcement Shortcuts 34

4 Conclusion 36

References 38 


\section{Introduction}

In the aftermath of the crisis of 2007-2008, financial institutions in several countries have experienced increased levels of litigation on allegations of misconduct and irresponsibility, a process that in the United States is metaphorically referred to as "Wall Street vs. Main Street". ${ }^{3}$ It is, however, surprising that extremely high levels of litigation involving clients and banks can also be found in Brazil - a country that has emerged from the crisis as having resilient financial markets, whose regulators have time and again been portrayed as poster children of responsible financial supervision, and whose banks have repeatedly been described as "conservative" (Barbosa, 2010: 9-10; Alves and Alves, 2010: 173-174; Toledo, 2010: 236).

For many years, Brazilian financial institutions have been involved in record high levels of litigation. A recent study showed that financial institutions are currently the largest private litigants before Brazilian courts, having been involved either as plaintiffs or defendants in $12,95 \%$ of all new lawsuits brought before State courts in Brazil ${ }^{4}$ between January 1, 2011 and October 31, 2011, (CNJ, 2012: 8). ${ }^{5}$ Considering only State small claims courts (Juizados Especiais Estaduais), ${ }^{6}$ the percentage increases to $14,7 \%$, with financial institutions as defendants in all but $0,02 \%$ of lawsuits (CNJ, 2012: 8). In Federal courts, ${ }^{7}$ the situation is only slightly better, with state-controlled financial institutions involved in 9,6\% of all new lawsuits (CNJ, 2012: 8). In addition, 28 of the 100 largest litigants in Brazilian State courts, and 35 out of the 100 largest litigants in State small claims courts, are financial institutions (CNJ, 2012: 15-23; 24-31). Striking as it may seem, 2011 was hardly an atypical year in what comes to financial

\footnotetext{
3 An earlier version of this paper was presented at a conference on Capital and Financial Markets - Post-Crisis Developments, hosted by Direito GV in São Paulo on May 27, 2013. The authors thank Morgan Ricks for helpful comments presented in that venue, as well as Pollyana Lima for research assistance.

A recent survey by the Wall Street Journal estimates that large global financial institutions may collectively spend US $\$ 100$ billion in the United States and the United Kingdom to cover litigation costs on alleged financial wrongdoings over the past five years. See WSJ (2013).

4 State courts in Brazil are courts of general jurisdiction.

5 The survey does not include criminal, electoral and military cases, as well as cases brought by the Public Prosecutor's Office. For further details on the methodology, see CNJ, 2012: 4-6.

6 Small claims courts in Brazil can only hear cases in which the amount involved is equal to or lower than forty times the minimum wage. As of March 2013, that amount is roughly equal to US\$ 14,000.00.

7 Federal courts have jurisdiction to hear cases involving the Federal government and entities controlled by it, including public financial institutions.
} 
market litigation in Brazil: a similar report published by CNJ in 2011 found that financial institutions were involved in 53,5\% of all lawsuits pending before State courts as of March 2010 (CNJ, 2011: 23).

To put these numbers in perspective, the second-largest private sector litigants in Brazil are telecom companies, which numbers are considerably lower: during the same period, they were responsible for 2,38\% of new lawsuits in State courts (or 4,5 times lower than banks) (CNJ, 2012: 8), and 8,3\% in State small claims courts (or a little over half the lawsuits in which banks are involved) (CNJ, 2012: 11). Most importantly, the existing levels of litigation with Brazilian financial institutions are largely unrelated to the recent international crisis, as existing lawsuits cover a wide range of matters, such as credit agreements, inflationary losses, tariffs, and foreclosures. Yet the most commonly litigated issue in courts is the interest rate charged by banks from their customers in credit transaction (Jantalia, 2012: 177).

This article analyzes the institutional drivers of such alarmingly high levels of litigation between clients and financial institutions in Brazil. In so doing, it posits the existence of two qualitatively different kinds of litigation between clients and banks, one circumstantial and the other structural. The increased levels of litigation in recent times in a country such as the United States can be said to be circumstantial, in the sense that it largely results from a specific set of events - alleged frauds and misconducts related to the housing and financial bubbles of the 2000 decade and the Libor rate-rigging scandal. Conversely, litigation between banks and clients in Brazil is not only circumstantial (as a result of several episodic economic plans of the past), but also structural in the sense that its underlying factors are much more complex and cannot be traced solely to one event or set of events.

Most of the policy oriented literature on financial market litigiousness in Brazil revolves around a discussion of the impacts of a perceived debtor-friendly bias of Brazilian institutions, including courts, on generating legal uncertainty and feedback loops that further increase interest rates (Fachada et al, 2003: 14-15; BCB, 2004: 35-36; Arida et al, 2005: 268; Saddi, 2007: 254-255). ${ }^{8}$ Some strands of this literature have gone as far as to suggest that the dearth of longterm financing by private banks in Brazil could mostly be attributed to lack of effective creditor protection in Brazil courts (Arida et al, 2005: 268). This literature carries a simple normative implication, namely that dealing with massive levels of litigation in Brazilian financial markets

8 Some scholars have attempted to challenge the perception that Brazilian courts have a debtor-friendly bias and foster judicial uncertainty. For examples, see Falcão et al (2006), Gonçalves et al (2007), Ribeiro (2007) and Silva et al (2012). 
requires increased legal certainty and greater protection of creditors, which is to be achieved basically through reforms in procedural and bankruptcy laws so as to expedite collection proceedings, and also a change of heart on the part of judges, who should more stringently uphold contractual provisions. The assumption is that greater legal certainty would entail a reduction in the overall levels of litigation, promoting more robust capital markets and improving capital allocation in general.

The main shortcoming of this literature is that it addresses the way courts behave once disputes reach their doorstep; conversely, our contribution is to take a step back with a view to understanding the underlying reasons for why such a large number of disputes end up in courts in the first place. Evidently, we agree that lack of legal certainty and the ease of access to costfree lawsuits in Brazil (Santos Filho and Timm, 2011) create feedback loops of additional litigation (by enticing opportunistic litigation by debtors, as argued by Falcão et al, 2006: 85-86) and higher interest rates (through adverse selection of debtors, as argued by Silva et al, 2012) . Indeed, the Brazilian financial and credit markets cannot be deemed to be normal in any meaningful sense if current levels of litigation do not recede.

However, we believe that solving the problem of extreme litigation in Brazilian financial markets requires much more than pinpointed changes in procedural, bankruptcy and collection laws, which is the basic menu of reforms being debated in Brazil since the late 1990s (BCB, 2004: 23-34; Fabiani, 2011: 133-147). Simply put, we contend that high levels of litigation in Brazilian credit markets is structural, because its root causes are far more complicated and much more deeply ingrained in the country's institutional system than is often acknowledged or understood. It is our view that endemic litigation in Brazilian financial markets is part of a broader political, economic and legal context, the details of which this article aims to unbound and explain.

In light of the above, the main ambition of this article is to formulate a narrative that identifies such structures and explains how they have come to shape, reinforce and sustain present levels of litigiousness. To do that, we approach the problem of high litigation in Brazilian credit markets holistically, and try to study not only why clients overwhelmingly rely on courts

9 It is worth fleshing out how adverse selection affects the Brazilian credit market. High base interest rates coupled with high spreads make credit extremely expensive to customers. Because of that, credit becomes attractive only to customers involved in riskier activities, who expect to obtain higher gains that will enable them to pay off expensive loans. As a result, only riskier borrowers will seek and obtain credit, driving up the risk faced by financial institutions and therefore the prices they charge for credit (Silva, 2012: 38-40; Salama, 2012: 165-166). 
as the venue to confront financial institutions, but also why courts are seemingly receptive to such plaintiffs.

Aside from illuminating the heated debate about interest rates and credit litigation in Brazil, our discussion contributes to three other sources of literature. First, it illuminates various aspects of the theoretical perspectives that form the backbone of the Regulatory State of the South (RSS). According to Dubash and Morgan (Dubash and Morgan, 2012), the RSS project seeks to understand the politics behind the rise of the regulatory state in the geopolitical South, and how such development was conditioned by "highly salient transnational pressure on the state, comparatively intense redistributive politics and limited state capacity" (Dubash and Morgan, 2012: 363-364). Prado and Urueña propose to take that investigation one step ahead, and understand when and how courts become "relevant actors in the resolution of underlying distributive issues related to the regulatory framework" in the global South (Prado and Ureña, 2013: 9). ${ }^{10}$ Although we perhaps fall short of a full-fledged theorization of litigiousness in Brazilian financial markets, our narrative shows how the transition to a constitutional democracy during the 1980 s brought courts from the periphery to the center of political decision making in Brazil. The consequence was that many of distributive conflicts that underlie banking regulation could no longer be dealt with solely within the administrative and legislative spheres.

Second, our discussion helps exemplify some of the insights of the Varieties of Capitalism project (Hall and Soskice, 2001). In the work that launched the project, Hall and Soskice point out that institutions condition the strategic relationship between actors in a way that creates expectations and affects political economy outcomes (Hall and Soskice, 2001: 5). They also point out that institutions themselves are both conditioned and influenced by their historical development (Hall and Soskice, 2001: 5). In discussing the impacts of litigation on credit markets, our work also exemplifies Salama's discussion of the "legal refraction" of macroeconomic policymaking in the context of the regulatory state (Salama, 2013b). Following those intuitions, we attempt to trace the history of the Brazilian Central Bank (BCB) as part of a larger economic, political and legal development that shaped its institutional characteristics.

10 The importance of courts as policy actors in the South had already been hinted in the works that accompanied Dubash and Morgan's initial statement of the RSS project (Dubash and Morgan, 2012). In their work on the role of courts in the regulation of telecommunications in India, Thiruvengadam and Joshi observe that " $(. .$.$) as$ scholars focus on the rise of the regulatory state in the Global South, they should focus in particular on the role of judiciaries (especially in jurisdictions where judicial systems have established some institutional credibility and independence) and on other institutions that could play a supportive or facilitative role similar to that which we have described" (Thiruvengadam and Joshi, 2012). 
Third, this article contributes to the discussion about the relative advantages and disadvantages of litigation and regulators in establishing efficient rules for markets to function healthily. Since Ronald Coase's classic piece of 1960, much debate has been ongoing over the topic (Coase, 1960: 19). In the United States in particular, an optimistic view of the Common Law has led many, and most notably Richard Posner, to favor judges over regulators (Posner, 2003, 1st ed. 1973). Indeed, since then much of Law \& Economics scholarship has been grounded on the notion that courts tend to improve rules over time (Cooter, Kornhauser and Lane, 1979; Rubin, 1977; Priest, 1977). The recent financial crisis of 2007-2008 has however reignited the debate, leading many, including Posner, to reassess some of its positions, particularly in the realm of financial regulation (Posner, 2009; Shleifer, 2012). The narrative contained in this article reinforces skepticism about the ability of courts to determine adequate rules for financial markets to function efficiently. Sadly for technocrats, however, it also points out that current political and economic structures have rendered it impossible for bureaucrats to devise a purely regulatory solution to the problem of excessive litigation in Brazilian financial markets.

The rest of this article is organized as follows. Section 2 traces the litigation in Brazilian credit and financial markets to an institutional letdown of the past that reverberates until today. We argue that in Brazil a Central Bank actually empowered to implement monetary policy was only created in the 1980 s, at a point where inflation was already out of control and the then ongoing political transition to democracy made it difficult for the Brazilian society to reach the difficult compromises necessary to fix a chronically budgetary problem of the state (Franco, 1996: 213-249). The result was the adoption of tight monetary policy, leading to high interest rates and soon high levels of litigation. To be more precise, even though the Brazilian Central Bank (BCB) was formally created in 1965, it was not until the 1980s that it acquired powers to semi-autonomously devise monetary policy. Adverse political circumstances paved the way to an environment of scarce, expensive - and here lies the Brazilian idiosyncrasy - highly litigated credit.

Section 3 explores economic, political and legal drivers of financial market litigiousness in Brazil. On the economic side, we trace high levels of litigation in Brazilian financial markets to a history of macroeconomic volatility aggravated by various far-reaching stabilization attempts. On the political sphere, we show how the constitutional pact of 1988 brought courts and judges to the forefront of the political debate, including in the sphere of finance and credit mobilization. We also explore how the political choice of adopting a consumption-based model of social inclusion since the early 2000s inflated credit levels by creating indirect incentives for 
citizens to take on loans. Finally, on the legal sphere, we show how the legal reforms brought by the 1988 Constitution increased the availability of judicial review and court's willingness to intervene in private contractual relations, especially in high-cost credit transactions.

Section 4 concludes by summarizing our institutional hypothesis and its implication for future policy-oriented research. We argue that the democratic transition in Brazil during the 1980s resulted in a new economic, political and legal context that clashed with the institutional setting of economic policy-making inherited from the years of military dictatorship. The explosive level of litigation that has now come to characterize Brazilian financial markets in general, and credit markets in particular, is not simply the result of poor procedural and civil laws, but rather an institutional byproduct of an unfinished transition. The key lesson is that high litigiousness became an impediment to the full normalization of the Brazilian economy, and that reforms will be at best partially successful unless they recognize, understand, and address the background institutional drivers of financial market litigiousness in Brazil.

\section{Inflation as the Root of All Evils: Monetary Disorder and the Institutional Letdown within the Brazilian Central Bank}

Understanding financial market litigiousness in Brazil requires an institutional reading of the evolution of its regulatory framework. In this section, we opt to conduct that narrative by focusing on the role of the Brazilian Central Bank (BCB), currently its most important regulatory body. Specifically, we describe the development of the BCB since its creation in 1964 in connection with the overall directions of Brazilian political economy, focusing on two main historical junctures: the 1986 budgetary reforms that extinguished the "conta movimento" (movement account) and moderately increased BCB's control over monetary policy, and the 1999 adoption of a formal inflation-targeting regime as part of the political pact to end inflation.

Our analysis shows that in spite of being a "nominally old" agency, the BCB is in fact a "functionally new" one (Prado, forthcoming: 16). When it was created in 1964, BCB had a very limited role in monetary policymaking, which was supposed to be its main institutional function. It was not until well into the 1980s that this situation began to change, in a long and slow transition completed only in the late 1990s, concomitantly with the broader movement that ultimately implemented the regulatory state in Brazil. 
When it comes to the regulation of the financial system, the BCB was relegated to a secondary role for most of its history, due to its formal subordination to the National Monetary Council $(\mathrm{CMN})$ and the political battles that continuously surrounded its exercise of monetary authority. Those characteristics influenced BCB's regulatory autonomy and the way it interacts with other institutions. Because its autonomy has been hard-won and historically constructed to depend on its policy success in fighting inflation, $\mathrm{BCB}$ is part of the institutional structure that resulted in what we call the "incomplete normalization" of Brazilian credit markets.

This scenario of "incomplete normalization" resulted in a dispute-prone environment of scarce and expensive credit, and created institutional conditions that underlie highly litigious financial markets. The basic point is that high levels of litigation in credit transactions in Brazil are also a function of the high levels of interest rates and spreads that have been practiced by Brazilian banks over the past two decades (Segura-Ubiergo, 2012: 3-4). Here, the intuition is simple: a judge is much more prone to overrule a contractual provision in a credit transaction where the monthly interest rate is 5\%, than in one where the annual interest rate is $5 \%$. For reasons that probably have to do with judges' deep-seated notions of fairness in exchange, ${ }^{11}$ the surprisingly high levels of interest rates that prevail in Brazilian credit markets create an implicit incentive for judges to intervene in private contracting.

\subsection{BCB's Path to Becoming a Monetary Authority (1964 - 1986)}

BCB was created in 1964 with the enactment of Law 4,595, and started operating in 1965. Its creation was part of a political compromise between the economic staff of President Castelo Branco, led by Minister of Finance Octávio Gouvêa de Bulhões and Minister of Planning Roberto Campos, who viewed a strong central bank as an important part for the modernization of the Brazilian economy, and the powerful bureaucracy of Banco do Brasil (BB) (Santos and Patrício, 2002: 98). Created in 1808 and then the oldest and largest Brazilian bank, BB was responsible for many of the functions usually associated with a central bank, and the enormous size of its balance sheet gave it a large political clout.

The opposition of BB to the creation of a central bank had already been challenged with

11 For a general discussion of fairness in exchange, see Gordley (1981). 
moderate success in 1945, when at the end of the Vargas dictatorship the government created Superintendência da Moeda e do Crédito (SUMOC) and transferred to it some of the responsibility for monetary policy (Taylor, 2009: 496). But the creation of SUMOC had little effect in the conduction of Brazilian economic policy in the long run, and BB was able to keep pulling the levers (Raposo and Kasahara, 2010: 930-931). That situation remained true even with the push by the military administration to replace SUMOC with CMN and create the BCB shortly after taking office, prompting Taylor to point out that " $[\mathrm{w}]$ holesale institutional reform was not a possibility even under authoritarian rule" (Taylor, 2009: 496).

One of the most powerful mechanisms that allowed BB to remain a powerful player in monetary policymaking, thus undermining BCB's institutional development, was the so called "conta movimento". This account was originally conceived to allow BB and the BCB to balance their transactions going forward, and its creation was part of a political compromise to speed up the approval of Law 4,595/64 (Nóbrega, 2005: 288-290; Taylor, 2009: 498). However, the movement account enabled the BB to create base money through an open Central Bank “discount" facility (Baer, 2001: 149). As a result, the account effectively became a funding mechanism that allowed BB to sustain its ever-increasing lending operations and in the process eroded BCB's control over monetary expansion (Taylor, 2009: 498). Therefore, BCB's role as a monetary authority was greatly jeopardized from the outset even though it enjoyed a moderate level of formal autonomy. ${ }^{12}$

In the few years following its creation, $\mathrm{BCB}$ was quickly subjected by the political realities and goals of the military administration (Santos and Patrício, 2002: 99). President Costa e Silva succeeded Castelo Branco in early 1967 and quickly moved to get a firmer grip on economic policy. He increased the power of the Ministry of Finance and sought to replace the Board of the BCB. Former Minister of Planning Roberto Campos once referred to a conversation during which he attempted to convince President Costa e Silva of the importance of an independent central bank to Brazil's economy by characterizing the BCB as the "the guardian of the currency", to which the President replied: "I am the guardian of the currency" (Taylor, 2009: 499; Raposo and Kasahara, 2010: 936).

President Costa e Silva was able to replace the President of the BCB and force the entire Board to resign (Raposo and Kasahara, 2010: 935-936). His administration also quickly

12 Pursuant to article 14 of Law 4,595/64 as originally enacted, the President and Directors of BCB enjoyed a fixed 6-year mandate as members of $\mathrm{CMN}$, which was designed to assure moderate stability and autonomy to $\mathrm{BCB}$ (Raposo and Kasahara, 2010: 933-934). 
approved Law 5,362, changing Law 4,595 to increase CMN membership to 10 members and to extend member's terms to 7 years. Over the following few years, the CMN became responsible for managing the national food supply policy ${ }^{13}$ and was expanded to reach 16 members in 1972. ${ }^{14}$ Those changes affected CMN's profile as a technical policymaking venue and further hindered the profile of the $\mathrm{BCB}$ as a monetary authority, even though its role in the supervision of the financial system is understood to have expanded as a result of the increased complexity of the Brazilian economy (Taylor, 2009: 499).

In 1974, following years of decline in BCB's autonomy in practice, President Geisel adopted a centralizing approach and finally revoked the fixed terms of BCB officials, making them removable at the President's will (Raposo and Kasahara, 2010: 938). ${ }^{15}$ Throughout the 1970s, BCB remained a secondary actor in Brazilian economic policy (Taylor, 2009: 499-500). The situation only began to change in the early 1980s, when the political backlash against the military rule and the pressure for democratization mounted and started a slow movement to open up the political environment, with sensible effects for monetary governance and authority (Sola et al, 2002).

In parallel to the political movement for democratization, the economic climate of the period also created the conditions for more significant reform. Brazilian public indebtedness had reached critical levels that strapped finances and strangled the economy, and Brazil soon faced a debt crisis. Inflation rates soared and its damaging effect on the population created great popular demand for solutions that would reestablish price stability (Taylor, 2009: 500). That combination of political and economic circumstances empowered politicians and policymakers to discuss and design solutions to strengthen BCB's monetary authority and diminish the role that political pressures played in Brazil's economy. In 1986, important reforms were implemented following a period of intense political struggle.

One of the most significant measures taken as part of the 1986 reforms was the elimination of the "conta movimento", which had allowed BB to circumvent BCB's control over monetary expansion. Without that loophole, BCB would be able to have a much better grip over economic policy. Another important step was the creation of the National Treasury, which took on from BCB the responsibility to manage public debt (Taylor, 2009: 501-502). With those

\footnotetext{
13 Article 2 of $65,769 / 69$.

14 Decree $71.097 / 72$.

15 Article 5 of Law 6.045/65
} 
measures, more than 20 years after its creation, BCB had finally taken the first important step to become a monetary authority.

\subsection{Consolidating Monetary and Regulatory Authority (1986 - 1999)}

Even with the 1986 reforms and the positive momentum towards becoming an independent monetary authority, there was still a long way to go (Taylor, 2009: 502). For starters, BCB was still subject to $\mathrm{CMN}$, and at that point $\mathrm{CMN}$ had been transformed in a large political and deliberative body composed of 27 members,${ }^{16}$ most of them being under the direct influence of the President. Therefore, CMN reunions were a mere formality, with all relevant decisions being made by the Ministry of Finance and BCB having very little influence in the policymaking process (Raposo and Kasahara, 2010: 941).

The approval of a new Constitution on October 5, 1988, represented an important landmark in the institutional history of BCB. It consolidated the victories achieved with the 1986 reforms and formally concentrated monetary authority exclusively in the hands of BCB (Taylor, 2009: 503; Santos and Patrício, 2002: 99). BCB Directors were now to be appointed by the President and approved by the Senate, increasing the level of legislative oversight. ${ }^{17}$ In what comes to the functioning of the financial system, the 1988 Constitution set forth that a Complementary $\operatorname{Law}^{18}$ was to be approved to replace Law 4,595 and regulate the financial system. ${ }^{19}$

President Collor was the first democratically elected leader following the demise of military rule and the approval of the 1988 Constitution. Early in his administration, he reformed

16 The last expansion had occurred in 1987, when Decree 94,303/87 included a representative of the unions among CMN members. The fact that the Decree was enacted on May 1, the International Worker's Day, is a sign of the political significance of the measure for the Sarney Administration.

17 Article 52, III, item d, of the 1988 Constitution.

18 Pursuant to article 69 of the 1988 Constitution, Complementary Laws need an absolute majority in Congress to be approved.

19 Article 192 of the 1988 Constitution. 
$\mathrm{CMN}$ to decrease its membership, first to 16 members ${ }^{20}$ and then to $17,{ }^{21}$ and his administration is credited with allowing great practical autonomy to the BCB. Ibrahim Eris, who presided BCB from March 1990 to May 1991, declared in an interview that during his tenure the bank enjoyed full autonomy to act, even though political and social issues were considered alongside technical aspects in BCB's decision-making process (Raposo and Kasahara, 2010: 941).

In 1992, President Collor resigned in the midst of corruption allegations, and his vicepresident Itamar Franco was inaugurated. President Franco reportedly considered BCB somewhat of a "black box" meriting close supervision (Raposo and Kasahara, 2010: 943), and therefore he initially reversed the practical autonomy that it had enjoyed during the Collor Administration. But the inflationary tragedy that had troubled Brazil since the 1980s had worsened following Collor's resignation, reaching the staggering level of $1,038.3 \%$ over the period (Raposo and Kasahara, 2010: 951). Since the most credible alternative to reduce inflation presented by his economic advisors, led by Minister of Finance Fernando Henrique Cardoso, called for an independent BCB, President Franco was forced to reconsider.

In June 1994, President Franco enacted Provisional Measure 542 to roll out the Real Plan, with the very ambitious goal of reducing inflation to acceptable levels and introducing a new currency. Policymakers believed that the success of the plan ultimately required a technical $\mathrm{CMN}$ and a $\mathrm{BCB}$ with strong operational autonomy. To isolate $\mathrm{CMN}$ from political pressure, its membership was reduced to 3 (Minister of Finance, Minister of Planning and the President of $\mathrm{BCB}$ ), the lowest headcount since its creation. ${ }^{22}$ In exchange for more operational autonomy, BCB would now be required to submit periodic reports to both the Senate and the House of Representatives, increasing the possibility of legislative oversight (Raposo and Kasahara, 2010: 945-946).

The striking success of the Real Plan in its first months propelled Minister Cardoso to win the 1994 Presidential elections. During his administration, President Cardoso strengthened the institutional framework necessary to assure the success of the Real plan, with BCB playing a paramount role in assuring monetary stability. In 1996, BCB created the Monetary Policy Committee (COPOM), a technical body composed by the President and the Directors of BCB with the responsibility to set monetary policy goals and the target interest rate in a technical,

\footnotetext{
20 Decree 99,207/90.

21 Law 8,056/90.

22 Article 8 of Law 9,069/95.
} 
transparent and accountable way (Santos and Patrício, 2002: 100-101).

Because the sudden drop of inflation and increased interest rates necessary to maintain stability threatened the health of several Brazilian banks, the Cardoso Administration launched through CMN a number of initiatives to restructure the national financial system. As a result, $\mathrm{BCB}$ was entrusted with executing an ambitious and high profile regulatory and supervisory agenda (Sobreira, 2011). From 1994 to 1998 BCB (i) kicked off the implementation of the Basel capital requirements in Brazil, (ii) managed the Stimulus Program for the Restructuring and Strengthening of the National Financial System (PROER), which provided incentives for health banks to acquire failing banks, (iii) supervised the creation of a deposit insurance scheme, the Credit Guarantee Fund (FGC), (iv) strengthened the supervision over offshore branches of Brazilian banks, (v) regulated bank tariffs, and (vi) implemented a Central System of Credit Risk (SCR) and (vii) managed the Incentive Program for the Reduction of State Participation Banking Activity (PROES), a privatization program to reorganize and privatize failing Statecontrolled banks (Sobreira, 2011: 895-898).

In 1999, the Cardoso Administration formally introduced an inflation-targeting regime in Brazil. Pursuant to Decree 3,088, CMN was made responsible for setting the inflation target and a corresponding tolerance level, and $\mathrm{BCB}$ was charged with executing the policies required to achieve the targets. It also requires BCB to publish quarterly inflation reports describing the measures adopted and the results achieved. The provisions of Decree 3,088 did not place any limitation on BCB's freedom to pursue price stability within the target set by CMN (Taylor, 2009: 509), thereby representing a legal recognition of its ample operational autonomy, even in the absence of formal independence.

\subsection{Incomplete Normalization and Institutional Limitations (1999 - Present)}

Since 1999, no major change has been made in the institutional framework of Brazilian monetary policymaking. The transition from the Cardoso Administration to the Silva Administration, which for a period during the 2002 Presidential elections caused great macroeconomic turmoil, did not change the level of operational autonomy enjoyed by BCB as part of his pledge to monetary stability (Taylor, 2009: 509). In fact, a significant change enacted by the Silva Administration elevated the President of BCB to the legal status of Minister 
for jurisdiction purposes. The change granted the Supreme Court original jurisdiction to hear any case in which the President of BCB is a party. The change aimed at insulating the BCB President from the politically motivated lawsuits that have historically targeted them for alleged wrongdoing in the conduction of monetary policy and bank supervision.

The main point of this section is therefore that the political, economic and institutional conditions for $\mathrm{BCB}$ to be able to effectively exercise its legally assigned duties were not present when it was created in 1964. Its current operational and regulatory capacity is the result of a slow and complex process of institutional development (Taylor, 2009; Santos and Patrício, 2002). For starters, BCB has always been formally subject to the policymaking authority of CMN (Salama, 2009, 114), so any significant exercise of its regulatory authority had to be grounded on a previously issued authorizing regulation. However, the political interests of the Presidency and the Ministry of Finance dominated CMN at least from 1967 to 1994. During that period, even financial institutions that were formally subject to BCB's supervisory authority were represented at $\mathrm{CMN}$, frequently in large enough numbers to outflank their regulator. ${ }^{23}$ During that period, BCB faced constraints in exercising its regulatory role in much the same way it did in exercising its monetary authority.

The changes brought by the 1988 Constitution affected both the monetary and the regulatory function of BCB. The requirement of a single Complementary Law to replace Law 4,595 reflected a compromise to postpone the discussion on how to better regulate the different aspects of the financial system due to lack of consensus in the Constitutional Assembly (Santos and Patrício, 2002: 100). But it also made it extremely hard for Congress to reach the level of consensus required to approve such a law, resulting in legislative inaction. In fact, a Constitutional Amendment approved in 2003 changed the provision that required the approval of a single Complementary Law, to allow for the approval of multiple ones instead. ${ }^{24}$ But almost ten years have passed since the change without any of such laws being approved.

With the lack of Congressional action to complete the regulatory framework of the financial system and the growing complexity of the Brazilian economy, CMN and BCB had to step in and fill the vacuum, significantly increasing their regulatory action while struggling with the constraints of operating under an antiquated legislative framework. From 1965 to 1988,

23 BB, Caixa Econômica Federal, Banco do Nordeste, Banco da Amazônia. From 1979 to 1990, for example, even the Director of the Foreign Exchange Desk of Banco do Brasil had seat on CMN.

24 Constitutional Amendment No. 40/03. 
CMN and BCB enacted a yearly average of 124 regulations (Rocha, 2004: 34). From 1989 to 2012 , that number increased almost tenfold, to an average of roughly 1221 regulations every year (Rocha, 2004: 34). ${ }^{25}$

The late 1980s also saw the rise of a growing consensus in international academic circles that independent central banks were fundamental to achieve price stability (Alesina and Summers, 1993). Economists had debated the relationship between price stability and the level of central bank independence over the previous decades, but it was only in the early 1990s that compelling evidence started to emerge and argue that a clear correlation existed between them (see Arnone et al for an extensive survey of the literature). ${ }^{26}$ As a result, the independence of central banks became a part of the policy recommendations actively advocated by international economic organizations, especially the IMF (Crowe and Meade, 2008; Raposo and Kasahara, 2010: 925-927).

Therefore, even though BCB is an almost 50-year-old agency, it shares two important institutional characteristics with the new agencies that were established in Brazil in the mid1990 s on. First, BCB's consolidation as regulatory authority in the 1990s, especially between 1994 and 1998, coincided with the period in which the majority of the new agencies was established. That explains our proposition that although BCB is a "nominally old" agency, it can in fact be considered a "functionally new" one (Prado, forthcoming: 16).

Second, central bank independence was an integral part of the liberalization agenda that spread throughout the developing work in the late 1990s, sparking contentions distributive issues. The international diffusion of the central bank independence agenda influenced policymaking in Brazil, which was undergoing a period of intense distributive conflict caused by economic reforms that aimed at opening up the Brazilian economy and eliminating entrenched rent-seeking behavior. In other words, $\mathrm{BCB}$ also shared with the new agencies that larger background context.

But differently from those agencies, BCB has been entrusted with what is probably a much more politically charged role: that of monetary authority. Because of that, "BCB-asregulator" has been constantly engulfed in the struggle for operational autonomy of "BCBas-monetary-authority", and both functions of the organization were equally affected by that

25 Rocha (2004) provides data from 1965 to 2003. Information on regulations enacted from 2004 to 2012 was obtained from the regulations search engine in the BCB website, available at: http://www.bcb.gov.br/?BUSCANORMA.

26 Some studies have empirically questioned the correlation between central bank independence and inflation. See, for example BARRO: 61-64. 
struggle through the years. Taylor correctly captures that when describing the institutional development of BCB as "halting and lengthy" (Taylor, 2009: 495). It was only in the late 1990s that BCB evolved to a point in which it was assigned primary and direct responsibility for achieving inflation targets, a conquer that Taylor points to as a result of previous successful policy outcomes (Taylor, 2009: 504).

The result of the political and economic developments described in this section is what we characterize as an "incomplete normalization" of Brazilian credit markets. On the one hand, the Brazilian economy has achieved normality in what comes to price stability, with inflation rates that are managed and closely monitored by the $\mathrm{BCB}$. On the other hand, however, interest rates have been kept abnormally high by BCB itself for most of the two decades since the Real was launched, due to the struggle to avoid inflationary pressures to which monetary policy was "locked" (Franco, 1996: 78-79; Oreiro et al, 2006: 618) and to the fact that BCB autonomy itself largely depended on its success in curbing inflation.

The extremely high basic interest rates set by $\mathrm{BCB}$ as a result of that dynamic also directly affect the price charged by its regulated entities in their lending transaction, and have been doing so for the past two decades. Expensive and scarce credit drives up moral hazard and results in a feedback loop of adverse selection, thereby increasing the risk faced by financial institutions and leading to even higher prices (Silva et al, 2012).

Furthermore, until very recently, Brazilian banks were only allowed to rely on a very limited information pool on the credit history of potential debtors, which made the adverse selection problem even worse. Until 2011, such pool could only include information on customer's actual defaults on obligations undertaken before other banks. Payment information on obligations such as utility bills was completely off-bounds. Also, since existing centralized systems would only register obligations above a certain amount, most of the transactions of the large and growing share of the population relying on smaller amounts of credit would remain outside of the system (Porto, 2010: 42-43). This is likely to change as BCB moves to implement more comprehensive credit history mechanisms following the enactment of Law 12,414 in July 201, but still far from having a sensible impact on credit availability and price.

In the next section, we will explore how the incomplete normalization, coupled with a host of economic, political and legal factors, has affected the level of litigiousness in Brazilian financial market, and how BCB's institutional development can be a significant explanatory factor to understand it. 


\section{Explanatory Factors of Credit Litigiousness in Brazil}

This section explores how economic, political and legal developments that took place over the past two decades helped shape and sustain the current scenario of "incomplete normalization" in Brazilian credit markets, in a way that resulted in the explosion of financial market litigiousness. Our focus is, therefore, not on what courts do when called on to decide disputes in financial markets, but on how they became such a powerful presence in financial markets.

\subsection{Overcoming the Conventional Wisdom on the Role of Courts in Brazilian Financial Markets}

The operational autonomy of the BCB from the early 1990s on was sustained by presidential support and its continued policy success in curbing inflation (Taylor, 2009: 507). The expectation of policymakers was that the normalization of inflation would ultimately cause other distortions in Brazilian economic policy to follow suit (Fabiani, 2011: 28). One of those distortions was Brazil's low level of credit as a share of gross national product, and the other was the extremely high interest rates and spreads charged from customers (Gonçalves et al, 2007: 50).

In January 1995, during the initial phase of the Real plan, the share of credit in Brazil's gross national product reached 36,9\% (Paula and Leal, 2006: 93). That number was expected to grow as a result of newfound economic stability and reduced inflation, but instead it experienced a slow decline over the next 5 years, reaching 27,9\% in 2000 and further declining until 2003 (Paula and Leal, 2006: 93). Cost was also a major concern. From 1996 to 2002, for example, Brazil's average short-term real interest rate was $14 \%$ per year, significantly higher than other developing nation such as Argentina (10,6\%), Poland (6,5\%), Mexico (4,6\%) and Turkey (2,6\%) (Gonçalves et al, 2007: 50). During the 1990s, the average spread charged by banks from individuals and companies in their credit transactions was of over $50 \%$ (Paula and Leal, 2006: 92). In 2012, Brazilian spreads of 27,8\% were also significantly higher than those charged in Mexico (3,82\%), South Africa (3,48\%) and Argentina (3,39\%) (DIEESE, 2012: 5). 
The expectation of policymakers was that credit would rise and spreads fall as a result of price stability, inflation targeting and a restructured and more competitive financial system (Oreiro et al, 2006: 610; Fabiani, 2011: 28). But with the macroeconomic puzzle largely solved in the late 1990s and no sign of significant improvement in credit offer and price levels as the end of the decade approached, policymakers began seeking alternative explanations. In 1999, BCB launched an effort to better understand the causes of large spreads and develop recommendations to bring it to sustainable level (Fabiani, 2011: 32).

As Fabiani describes, from 1999 on, the focus of debates in Brazil shifted from macroeconomic factors to Brazil's perceived institutional failures. Animated by an international wave where courts were increasingly seen as guarantors of property rights and stability, the so called "jurisdictional uncertainty hypothesis" gained ground in policy debates in Brazil. First advanced by Persio Arida, Edmar Lisboa Bacha and André Lara-Resende, this is the conjecture that the inexistence of a local long-term domestic credit markets in Brazil could be largely attributed to the "the uncertainties associated to the settlement of contracts in the Brazilian jurisdiction" (Arida et al: 268). Accordingly, the two main culprits in Brazil's credit markets were low levels of creditor protection and the ineffectiveness of Brazilian courts to assure timely and predictable contract enforcement (Fabiani, 2011: 32). ${ }^{27}$ Predictably, the development of those explanations in Brazil coincided with the increased acceptance of the Law \& Finance perspective in international academic and policymaking circles (La Porta et al, 2008; Fabiani, 2011: $54)$.

The Law \& Finance literature attempts to explain how the characteristics of different legal families lead to variations in investor protection, law enforcement and other corporate governance rules across nations in a way that accounts for the uneven development of corporate finance worldwide (La Porta et al, 1998: 1151-1152). According to its proponents, weak investor protection negatively affects financial development and growth (La Porta et al, 1998: 1152), and improving debt enforcement procedures would have a beneficial impact in developing

27 Salama (2012) points out that the debate in the economics literature about the causes of high interest rates in Brazil has clustered around five grand theories: "the fragility of public accounts, the thesis of reduced effectiveness of monetary policy, the Bresser-Nakano hypothesis, the convection-effect theory, and, finally the jurisdictional uncertainty" (Salama, 2012: 164; for a more detailed analysis of the five grand theories, see Modenesi and Modenesi, 2010: 8-15). However, only the jurisdictional uncertainty hypothesis proved to be a fertile starting point for policymakers to develop practical recommendations for institutional reform, and therefore it achieved a greater level of influence. 
economies (Djankov et al, 2008). ${ }^{28}$ As Fabiani explains, BCB's policy recommendations from the late 1990s on embraced the underlying assumptions of the Law \& Finance literature that law should be regarded as a "support to economic activity" (Fabiani, 2011: 124).

As a result, an influential literature began to evolve in Brazil to argue that weak creditor rights and jurisdictional uncertainty could explain why credit in Brazil remains scarce and expensive (Pinheiro and Cabral, 1998; Arida et al, 2004; Aith, 2009; Jantalia, 2012: 264), an explanation that we dub as the "conventional wisdom" on the relationship between courts and credit in Brazil. That literature took hold of policymakers, and most importantly, of the BCB.

Since 1999, BCB has advocated for institutional and legal reforms as a strategy to drive down spreads and incentivize the growth of credit markets, advocating for reforms such as the creation of a bank credit note to speed up debt recovery, the extension of the fiduciary sale regime to cover intangible and replaceable assets, the reform of bankruptcy legislation, extension of payroll loans to private sector workers, among others (Costa and Mello, 2009: 160; Fabiani, 2011: 59; 133-147; Silva et al, 2012: 32-33; Jantalia, 2012: 166-167). Those efforts helped consolidate a view that Brazilian courts have an "anti-creditor bias" that causes jurisdictional uncertainty (Arida et al, 2005: 273) and that they are at least willing to interfere in private agreements (Salama, 2012: 162). Based on that perception, strengthening creditor rights and assuring faster and more efficient enforcement of contractual rights through legal reform would be a key policy objective to unlock Brazilian credit markets.

That literature, however, suffers from an important gap: it does not attempt to understand why courts have such an active and disproportionally large role in Brazilian financial markets, especially if compared to other sectors of the economy. As described in the introductory section of this paper, the legal relationship between a financial institution and one of its customers is 4,5 times more likely to end up in court than in the second most litigious economic sector, and every other case pending before State courts in Brazil nowadays involves a financial institution.

Despite that scenario, Brazilian literature on the relationship between courts and financial markets has overlooked what we believe is a fundamental question: what are the institutional determinants that so often drive parties in financial markets to courts in the first place?

28 A growing and influential body of literature has emerged since the late 1990s that questions the conclusions of the Law \& Finance project in what comes to the beneficial effects of legal transplants in developing and transition economies. This critical literature emphasizes functional substitutes and argues, for example, that effective institutions are much more important for long-term development than the mere adoption of foreign rules (Pistor et al, 2000). 
Even if courts do indeed have a debtor-friendly bias, what engenders it? We believe that seeking an answer to that question is an important step in the effort to develop policy recommendations to achieve the normalization of Brazilian credit markets. Nevertheless, the question has not received significant attention from academics and policymakers, who focus instead on investigating and evaluating what courts do once the dispute reaches their doorsteps.

Reforming the Judiciary and giving creditors more powerful instruments to enforce their agreements may well be desirable policy outcomes in their own right. But both are unlikely to achieve meaningful results in unlocking credit unless they are coupled with simultaneous reforms that address the background reasons that lead parties to seek relief from courts. In this section, we therefore attempt to overcome the conventional wisdom described above and develop a new one, in the form of a theoretical hypothesis to explain why Brazilian financial markets are prone to high level of litigiousness. To do so, we will follow the analytical strategy used by Salama (2012) to examine factors that influence the interpretation of banking agreements in Brazil, and explore the economic, political and legal aspects of the problem.

A brief methodological note is in order: we have opted to deal with each of those aspects separately for clarity purposes only. This choice by no means should be construed as a suggestion that the effects of each aspect can be isolated and dealt with separately. In fact, they exist in close connection with each other, and create mutually reinforcing pressures that contribute to the phenomenon. ${ }^{29}$

\subsection{Economic Aspects}

As described above, during the past two decades, the Brazilian economy has gone through a process that we characterize as an "incomplete normalization" - a process characterized by scarce and expensive credit even in an environment of controlled inflation and relative macroeconomic stability. In this section, we will explore how that process affected the type and

29 The following metaphor developed by Salama (2012) is useful to understand our approach and the relationship of each aspect with each other: "In physics, we learn that the resulting force is always obtained by the sum of the vectors of the other forces that integrate the system. For example, if many cars collide in a city crossing, the cars will be dragged in the pavement in a new direction, which will be the result of the original force of each car, subject to gravity and friction. Those ideas offer us a good metaphor to think about the evolution of court precedents on banking agreements, and credit agreements in particular" (Salama, 2012: 158). 
scale of legal challenges involving financial institutions that ended up in courts. Two explanatory factors are fundamental to understand that process and its ensuing effect in financial market litigiousness, and both of them are closely related to structural features of Brazilian economic policy in the past few decades: (a) the implementation of various economic stabilization plans from the early 1980s until 1994, (b) the macroeconomic challenges and shocks that continued to affect the Brazilian economy after 1994.

\subsubsection{Economic Plans: Learning to Expect the Unexpected}

During the 1980s, the Brazilian economy was struggling with monetary disorder and sky-high levels of inflation (Franco, 2004: 8-9; Salama, 2012: 161). The perception among policymakers was that a radical and encompassing solution was needed to bring about stability, and that belief led to a number of large-scale economic stabilization plans. Between 1979 and 1991, Brazilian authorities announced and implemented 10 economic stabilization plans and numerous other wage and price control initiatives, and none of them was success in curbing inflation in the long run (Castro and Carvalho, 2002: 122; Franco, 2004: 8-9).

Each of those plans entailed a number of reforms that sought to effectively reboot the Brazilian economy, and it was inevitable that each of them would be accompanied by government interference in private legal relationships (Duran, 2010). The plans involved measures such as replacing the currency, limiting the ability of private parties to set and adjust prices, interfering with existing contracts, changing rules to remunerate deposits, and confiscating private savings, among others (Castro and Carvalho, 2002; Wald, 2002: 39-43; Salama, 2012: 161). Considering the severity of the reforms and the resulting generalized perception of legal instability, it was only natural that the controversies would end up in the Judiciary, resulting in mass litigation with a very salient distributive component that gave rise to a judicial culture in which intervention in financial market agreements was seen as a ways to seek balanced solutions (Salama, 2012, 161-162).

According the National Confederation of the Financial System (CONSIF), an industry group of financial institution, as of early 2009 there were more than 550,000 pending lawsuits by plaintiffs demanding compensation for losses associated with stabilization plans introduced between 1986 and 1991 (CONSIF, 2009). BCB estimates that, should plaintiffs prevail in such 
lawsuits, Brazilian financial institutions would be faced with a $\mathrm{R} \$ 105$ billion bill, and therefore BCB has urged Brazilian courts to dismiss such challenges (BCB, 2010, p 293).

The success of the Real plan in curbing inflation in the early 1990s interrupted the series of failed economic stabilization plans. The past decade of relative macroeconomic stability has kept courts free from additional waves of challenges to large-scale stabilization efforts. However, it will still take many years for courts to finally settle existing ${ }^{30}$ and potential lawsuits in connection with previously implemented plans, and in any case future occasional economic shocks will continue to be a source of high litigiousness.

\subsubsection{Structural Challenges and Macroeconomic Shocks: Stability, Ma Non Troppo}

As recent studies acknowledge, microeconomic and institutional factors provide only a partial explanation for the high cost of credit that has prevailed in Brazil following the success of the Real plan, and monetary and fiscal issues may in fact be the most important factors to be considered in discussing policy solutions (Oreiro et al, 2006; Gonçalves et al, 2007, Manhiça and Jorge, 2012). Despite the overall stability of its economy from 1994 on, Brazil still faces structural challenges and occasional moments of macroeconomic uncertainty that continuously test the resilience of its credit markets and financial institutions' risk appetite (Paula and Leal, 2006: 100; Oliveira and Carvalho, 2007: 400).

As Oliveira and Carvalho point out, financial institutions in Brazil continue to face strong disincentives to provide credit in spite of the relative stability of the economy (Oliveira and Carvalho, 2007). Those disincentives are put in place by the very structure of the monetary regime implemented in Brazil from 1994 to 1999. In order to sustain low levels of inflation, $\mathrm{BCB}$ has been forced to sustain high basic interest rate targets. And since the basic interest rate set by $\mathrm{BCB}$ is the rate used by the government to obtain credit, which is considered almost risk-free and does not affect the regulatory capital thresholds of financial institutions, lending to the government is an extremely attractive investment opportunity to banks (Oreiro et al, 2006: 626). Other financial assets, such as bonds and securities, are also seen as better

30 The Supreme Court is still examining pending lawsuits discussing the constitutionality of such plans, and the decisions to be issued will certainly have a significant impact (Duran, 2010: 196). Even the Real plan is still being questioned regardless of its success, although to a much lesser extent (Duran, 2009: 216-217). 
revenue sources than the risky business of lending.

Given the availability of such alternatives, banks become less willing to provide credit to private parties, and only do so at high premiums. ${ }^{31}$ As a result, interest rates become even higher than they would otherwise be. Oliveira and Carvalho refer to this problem as the "opportunity cost" component of bank spreads in Brazil (Oliveira and Carvalho, 2007: 372). The authors show that between 2000 and 2005, the average share of credit transactions in total bank assets was 32,4\%, while bonds and securities represented a very close 29,3\% (Oliveira and Carvalho, 2007: 394). Bonds and securities also represented an important source of revenue for banks during the period, averaging $35,5 \%$ compared to the $56,6 \%$ share of financial intermediation (Oliveira and Carvalho, 2007: 396). It is somewhat optimistic to expect that banks will increase lending when they can obtain such a large chunk of their revenues with investment that involve less risk than even the safest of debtors, or that they would do so without attaching a high premium.

Apart from structural distortions, macroeconomic shocks have also contributed to the risk-averse approach of Brazilian banks and their tendency to charge high spreads. In early 1999, for instance, BCB was forced by market volatility to relinquish control over the exchange rate between the Real and the U.S. dollar, which had been managed as part of the strategy to transfer monetary power to BCB and curb inflation (Taylor, 2009: 506). From 1994 to 1999, $\mathrm{BCB}$ closely monitored foreign exchange markets, interfering to stop excessive devaluations of the Real. In January 13, 1999, market pressure reached unsustainable levels and BCB stopped managing the exchange rate: by January 31, 1999, U.S. dollar went up 63,7\% (Souza et al, 2006: 203).

The sudden and dramatic devaluation of the Real affected numerous contracts but most notably automotive leasing agreements, which outstanding amounts were adjusted based on the exchange rate for U.S. dollars (Bertran, 2008). Literally overnight, debtors witnessed their debt grow by more than 50\% (Salama, 2012: 162). Debtors that could not renegotiate their debt had no choice but resort to courts to argue against the excessive burden brought by devaluation, and a wave of lawsuits followed (including a high-profile class action against 26 major leasing providers) (Vianna and Burgos, 2005: 820-821; Palhares, 2012: 341). Courts initially sided with consumers, directing creditors to change the adjustment criteria. Later, courts decided that the best solution was to split the different, or even to nullify the adjustment clause only when the

31 This is the essence of the adverse selection mechanism in financial markets. See note 8 above. 
leasing provider was unable to prove that its funding source was also subject to the variation (Palhares, 2012: 343-344).

Shortly after the 1999 devaluation, Brazil underwent a period of intense uncertainty during the 2002 Presidential elections. The expected victory of Mr. Luiz Inácio Lula da Silva, a left-wing labor leader of the Worker's Party with a history of arguing against economic stability, fiscal control, open economy and privatization, led investors to fear for the continuity of the Real plan. During the last semester of 2002, the Real continued to loose value against the U.S. dollar and credit remained locked. Mr. Silva was forced to pledge to keep the fundamentals of Brazilian macroeconomic policy unchanged, and investors eventually resumed normal behavior after his election (Taylor, 2009: 509; Manhiça and Jorge, 2012: 33).

In 2008, the Subprime Crisis hit, and even though its effect in the Brazilian economy were far from catastrophic, financial institutions expectably reacted by lending less and charging more. As Freitas described, financial institutions faced the prospect of a US\$25 billion loss in derivatives entered into with 3,000 companies, and the uncertainty over these and other losses and systemic issued led banks to raise their risk premiums (Freitas, 2009: 137).

The notion of "incomplete normalization" captures the essence of our argument. The host of structural distortions and occasional macroeconomic shocks that affected the Brazilian economy following the stabilization policies of the 1990s had a large role in keeping credit expensive and scarce, and such high number is a fundamental driver of financial market litigiousness.

\subsection{Political Aspects}

Political aspects are also an important aspect of financial market litigiousness in Brazil, to the extent that they affect citizen's perception of BCB as a credible venue to voice their grievances against financial institutions. We believe that three circumstances provide an explanation for how that perception plays out in Brazil: (a) the Centrality of Courts in the Post-1988 political arrangement in Brazil; (b) the natural opaqueness of $\mathrm{CMN}$ and $\mathrm{BCB}$ rulemaking procedures, and (c) the political choice to foster financial and social inclusion in Brazil through consumption incentives, especially from the 2000 s on. 


\subsubsection{The Centrality of Courts in the Post-1988 Political Arrangement in Brazil}

The end of dictatorship in Brazil brought with it a newfound trust in the legal profession as an instrument to achieve social transformation and consolidate democracy. As Oscar Vilhena Vieira puts it, Brazilian courts - and the Federal Supreme Court (STF) in particular - were entrusted with a role comparable to that of a "Moderating Power" (Vieira, 2010).

Thus, the Judiciary took on the role of arbitrating major institutional and political conflicts, a function that had been historically carried out by the military. It also started to act with increasing eagerness in matters of public policy design in Brazil, either by serving as a counterbalance or by prompting action. In both cases, the Judiciary is now a major influence in shaping incentives to economic action, some of which are positive, some of which not so much. It's as if the Judiciary is being pushed - sometimes rather willingly - to become an important and sometimes leading actor in the public policy-making field on Brazil.

Oscar Vilhena Vieira sums that up by pointing out that we currently live in a "supremocracia" (Vieira, 2008), wordplay with the Portuguese-language words "Supremo" (supreme) and "Democracia" (democracy) meant to highlight how, in Brazil, the expansion of courts' authority has been especially successful. That movement has obvious impacts on dispute-resolution in financial markets: in the post-1988 political arrangement, courts are ready, willing and able to adjudicate disputes between citizens and banks. Especially when citizens have limited alternative channels to seek redress.

\subsubsection{Opaque Regulatory Process}

As described in Section 2, the exercise of regulatory power by CMN and BCB greatly intensified following the approval of the 1988 Constitution. Since then, the high level of consensus required in the Constitution for the approval of a new regulatory structure for the Brazilian financial system - even following the 2003 reforms - has prevented Congress from replacing Law 4595/64. But CMN and BCB have had no choice but to deal with the practical necessities of regulating a large and complex economy undergoing a period of intense modernization, especially after 1994, and to do so under a legal framework that had been put in place 
at the outset of a dictatorship.

This contradiction has sparked debates among scholars of Brazilian administrative law on whether the regulations issued by $\mathrm{CMN}$ and $\mathrm{BCB}$ violate the 1988 Constitution by extrapolating the boundaries of agency rulemaking power. As Rocha summarizes it, two bodies of literature have emerged that hold opposite views on the matter (Rocha, 2004: 13). A group of scholars sometimes referred to as methodologically "traditional" scholars argues that most of the regulations issued by both institutions are unconstitutional (Rocha, 2004: 14). Another body of scholars believes the rulemaking by $\mathrm{CMN}$ and $\mathrm{BCB}$ is a necessary consequence the technical complexity and agility required in regulating financial markets (Rocha, 2004: 68). Both views lead to a general consensus among scholars that there is a significant democratic deficit in the rulemaking activity of $\mathrm{CMN}$ and $\mathrm{BCB}$ (Rocha, 2004: 23).

In fact, both $\mathrm{CMN}$ and $\mathrm{BCB}$ have always had extraordinarily opaque rulemaking procedures. In the case of CMN, although its membership was relatively large during the first 30 years, it largely served to validate decisions taken by the President. Even with the democratization process of the early 1980s and the 1988 Constitution, CMN remained mostly closed to political contestation. The 1994 reform that shrunk its membership did not change that, as it was in part justified as a measure to avoid excessive participation of the private sector in monetary policymaking (Rocha, 2004: 167-168). The same was true for BCB rulemaking, which contains not meaning channel for public participation.

The rulemaking structure of $\mathrm{CMN}$ and $\mathrm{BCB}$ have effectively excluded citizens and nonindustry interest groups, and presented little (if any) opportunity for those groups to voice their concerns or prompt the regulator to act. The democratic deficit is further complicated by the high technical content of the regulatory and enforcement decisions taken by CMN and BCB. Taken together, those factors isolated $\mathrm{CMN}$ and $\mathrm{BCB}$ from political pressure, but also made them impermeable to the concerns and grievances of ordinary citizens, a barrier that they did not have to face when resorting to courts.

We of course recognize that the democratic deficit and the high technical content of financial regulation pose a problem not only in Brazil, but everywhere. The challenges of financial policy-making frequently require a highly specialized and nimble bureaucracy which is not always capable of engaging broader segments of the society in a meaningful way. Our goal here is merely to point out that, in Brazil, the natural democratic paradoxes that affect financial regulation in modern economies acts as an additional incentive for people to rely on courts as a venue to discuss their relationship with the industry. 


\subsubsection{Consumption-Driven Social Inclusion Strategy}

Since a little over a decade ago, Brazil has been going through a process of financial and social inclusion of its less affluent population which has generated a heated debate on the rise of a "new middle class" (Neri, 2010; Scalon and Salata, 2012: 388-399). One of the hallmarks of this process has been the adoption of policies geared at assuring that increasingly larger shares of the population have access to appliances and other more expensive durable goods (including cars), through consumer credit transactions (Scalon and Salata, 2012: 401; Bielschowsky, 2012: 738). This was done not only be seeking the reduction of interest rates in credit transactions (an initiative that was only possible due to the sharp reduction of base interest rates worldwide), but also through the adoption of a mixture of indirect incentives and the instrumental use of its gargantuan public banks (Paim, 2013; S\&P, 2012). ${ }^{32}$

It is fair to say that such a policy promoted financial inclusion. From 2003 to 2010, the Brazilian credit-to-GDP ratio has in fact increased from 23,7\% to 44,6\%, (Novais and Cagnin, 2011: 22), reaching 48,8\% in January 2012 (DIEESE, 2012: 2). Credit to individuals was responsible for generating more than one-third of such growth until 2010 (Novais and Cagnin, 2011: 22). But the costs of such policy in an environment of continuously high interest rates and spreads have started to show, and to sound alarms (IMF, 2012; S\&P, 2012). In its 2012 Financial System Stability Report on Brazil, the IMF has voiced some concern with the level of indebtedness of Brazilian families (IMF, 2012: 14). According to the Report, the Brazilian household debt service-to-disposable income ratio (DSTI) of 23\% is high if compared to similar developing economies (IMF, 2012: 15), and household indebtedness has been showing signs of distress and increased delinquency rates, which jumped to 7,6\% in early 2012 from 2\% in December 2010 (IMF, 2012: 16).

The political option for a growth model based on consumption and consumer credit in an environment of high interest rates certainly worsened the adverse selection problem to which Brazilian financial markets has been structurally prone. Therefore, the model described above has strong elements that probably made it a strong driver of financial market litigiousness over the last decade. Worse than that, its effects will most likely continue to materialize over time if delinquency rates continue to rise over time (IMF, 2012: 16).

32 The share of public banks in the total amount of credit in the Brazilian economy has risen from 38,9\% in 2004 to $42,2 \%$ in 2011 (Paim, 2013: 39). 
It must be noted, however, that the Rousseff Administration has shown some concern with this model. The government is well aware that growing delinquency would make the interest rate problem even worse, by creating a spiral of risk-compensating behavior by financial institutions. As BCB has dropped interest rates throughout 2012, the government started publicly pestering banks to lower the interest rates charged from consumers, and has also directed public banks to slash their rates, trusting that the fear of losing market share would prompt private banks to do the same (DIEESE, 2012: 14). The strategy adopted by the government has shown signs of success, and interest rates charged from consumers have indeed dropped, but remain one of the highest in the world, ${ }^{33}$ and it is still too early to assess its effect on delinquency rates and related litigation.

\subsection{Legal Aspects}

The 1988 Constitutions brought significant changes to Brazilian legal environment. Some of those changes contributed the increased reliance on courts as significant policy actors, and to the scope of action available to courts, therefore creating conditions to increased litigiousness in general and in financial markets in particular. We will focus on the three elements we believe to be more significant: (a) the dominant political philosophy behind the 1988 constitutionalization of rights and the idea that law has an explicit "social function", (b) the organizational reform to increase judicial independence and the availability of judicial review, and (c) the practical policy outcomes of an effort by BCB and financial institutions to seek legal enforcement shortcuts to assure and speed up recovery.

\subsubsection{Constitutionalism and Clashing Legal Cultures in Financial Regulation}

The 1988 Constitution is widely known in Brazil as the "Citizen Constitution". The expression highlights the extent to which the document incorporates a long list of legal, political,

33 On May 29, 2013, Brazil's basic interest rate of 8\% was the world's fourth highest rate (Valor Econômico, 2013). 
social and economic aspirations to empower the polity to seek and fulfill its democratic aspirations. Among the long list of rights guaranteed in the 1988 Constitution are rights to housing, education, leisure, minimum wage and retirement. ${ }^{34}$ It even contains a provision to protect workers from the effects of automation. ${ }^{35}$ It also set forth that private property is to be used so as to fulfill its "social function". ${ }^{36}$ But the larger long-term impact of the 1988 Constitution has most likely been the creation of underlying conditions for the rise of a renewed legal culture.

In an article on the development of banking law jurisprudence in Brazil, Salama explores four ways in which the political ideas and aspirations that undergird the 1988 Constitution allowed a renewed legal culture to flourish. First, the then-prevailing formalistic understanding of the law gave way to a more realistic approach, one that considered factual circumstances and the background objectives of legal forms when applying the law. Second, a form of neo-constitutionalism arose and gave greater weight to legal principles rather than formal rules when applying the law. Third, civil and commercial law, traditionally subject to the logic of private law, became embedded in an encompassing public law infrastructure. Fourth, all fields of law, including banking law, were understood to have underlying objectives, or "functions", which should drive its interpretation and application (Salama, 2012: 166-169).

The influence of those elements is evident in how the 1988 Constitution regulated financial markets. In accordance with the original language of article 192 of the 1988 Constitution, the national financial system should be structured so as to "promote the balanced development" of Brazil and to "serve the collective interest". In one of its more controversial provisions, article 192 also limited the interest rates that could be charged in credit transactions to $12 \%$ an year. Anyone who charged an interest rate higher than that would be subject to criminal prosecution.

But the democratic logic brought by the new constitutional arrangement could not seamlessly replace the logic of authority and close political control over monetary policymaking and financial regulation that had historically prevailed in financial market regulation (Salama, 2009: 109-110). This phenomenon is not new: the transition from the authoritarian rule of President Vargas to a democratic regime had caused similar contradictions and allowed antiquated rules to survive the erosion of the political conditions that sustained them (Salama, 2010a).

As the Brazilian financial system evolved through the 1990s, different regulatory policies

\footnotetext{
34 Article 7.

35 Article 7, item XXVII.

36 Article 5, item XXIII.
} 
and corresponding legal instruments were enacted, but the policies and legal instruments inherited from previous authoritarian regimes were not always altogether replaced or updated. As a result, many laws and regulations survived their political and economic momentum, but remain in effect under a new constitutional order. Their interpretation and application are sources of great legal uncertainty, and regulators contribute a fair share (Salama, 2010a). ${ }^{37}$

A very recent example illustrates this argument. On February 19, 2013, BCB enacted Ruling 4,187/13, revoking the Norms and Instructions Manual (MNI), a compilation created in 1978 to consolidate sparse regulations issued by BCB. When MNI was put in place, the goal of $\mathrm{BCB}$ was to provide financial institutions with a more rational and modern regulatory framework: one of its provisions declared that certain rules enacted in the 1960s were "out of use". But upon revoking MNI in early 2013, BCB confirmed the effectiveness of a number of those regulations that had been declared to be "out of use" by MNI. Therefore, a number of outdated regulations have now had their effectiveness confirmed after decades of uncertainty about what BCB meant with "out of use" in the first place. ${ }^{38}$

According to Salama, interpreting and applying financial regulatory instruments following the 1988 Constitution requires as understanding of three underlying aspects: first, the increased technical instrumentality of financial regulation, which means that rules should be applied with their specific end in mind; second, the specific logic of financial regulation, which is reflected in its principles and precedents; third, the limitations placed by the new constitutional order (Salama, 2009: 117). Those aspects are of course not always aligned, and have played out in a number of constitutional and legal controversies that arose under the 1988 Constitution.

A limitation on interest rates inscribed in the 1988 constitution is probably the most telling example of a sort of "legislative populism" that often emerged as the idea that the financial system should serve a "social" purpose gained ground with Brazilian politicians. Under article 192, Congress established a vaguely worded provision fixing "real" interest rates at 12 percent a year - and that happened in a context of monetary and economic disarray, where inflationadjusted interest rates charged by banks could easily reach hundreds of percentage points per

37 For a detailed analysis of how that contradiction plays out in the foreign exchange market in Brazil, see Salama (2010a).

38 To paraphrase a famous quote by U.S. Supreme Court Justice Antonin Scalia in his concurring opinion in Lamb's Chapel v. Center Moriches Union Free School District: "[1]ike some ghoul in a late night horror movie that repeatedly sits up in its grave and shuffles abroad, after being repeatedly killed and buried", outdated regulations stalk our financial system once again. 
year. Had this constitutional celing been fully applied, it would have caused disastrous effects in the financial system because essentially no existing credit transaction would be compliant. But on the night before the promulgation of the 1988 Constitution, President Sarney instructed the General Counsel to the Republic to draft an opinion arguing that the limitation did not have immediate effect, meaning that it needed to be regulated by the Complimentary Law referred to in article 192 of the 1988 Constitution before being applicable (Rocha, 2004: 135). President Sarney then approved the opinion, binding the Executive branch (including BCB).

The opposition quickly sued, urging the Supreme Court to strike down the opinion and declare the limitation to be immediately applicable. But the Supreme Court sided with the Executive and upheld the opinion: the constitutional order and the logic of financial markets had clashed, and the latter prevailed. It is interesting to note that BCB submitted an amicus curiae brief in this case urging the Supreme Court to uphold the opinion, arguing that giving immediate effect to the limitation would bring disastrous economic consequences (Rocha, 2004: 139). In any case, the point to be highlighted is that the 12 percent ceiling was litigated for many years in lower courts, until it was finally repealed in 2003.

Similarly to what occurred in the interest rate limitation case, the Supreme Court was called upon on multiple occasions since 1988 to interpret the Constitution as it applied to the regulatory powers of $\mathrm{CMN}$ and $\mathrm{BCB}$ and the legal framework of the financial system. ${ }^{39}$ In most of the cases, the Supreme Court upheld the results of the political process and the actions of the regulators, affirming their authority. The Supreme Court has also taken a close look into considerations about the practical consequences of its decisions over financial markets when deciding cases (Duran-Ferreira, 2009: 87). This position is consistent with

In a landmark case decided in 2006, however, the Supreme Court took a more active approach. In a constitutionality challenge initiated by CONSIF, the Supreme Court was asked to decide whether the Consumer Defense Code (CDC) was applicable to the relationship between banks and their customers, including credit agreements. In its decision, the Supreme Court affirmed the constitutionality of the CDC provision. With that, a number of principles and legal concepts that permeate consumer relations became applicable to banks, such as the principle of the objective good faith (Palhares, 2012: 330-331). ${ }^{40}$

39 For a detailed analysis of those cases and how the Supreme Court decisions influenced the regulatory environment of the financial system, see Pereira Júnior (2008), Duran-Ferreira (2009), and Duran (2010).

40 The principle of objective good faith is described by Palhares as having "a fundamental role as a 'bridge' between private law and the values expressly enshrined in the Federal Constitution" (Palhares, 2012: 332-333). 
What is interesting about the decision for purposes of our argument is that it put an end to a discussion that had created judicial uncertainty since the CDC was enacted in 1990, giving judges a new tool to interpret and assess financial agreements. Coupled with a constitutional framework that affirmed the social function of property and also of banking law, and assured broad rights to protect citizens, the decision established firmer and wider legal grounds for citizens to seek judicial relief against the terms and conditions of their agreements with financial institutions, regardless of its effect in the functioning of financial markets.

\subsubsection{Judicial Independence and Review Standards}

Apart from providing the legal underpinning for the renewal of Brazilian legal culture, the 1988 Constitution also provided the legal basis for courts to take on a new significance in the Brazilian legal system. Courts had been greatly empowered in the new constitutional regime, and quickly undertook their role in protecting citizens from arbitrary action by the government and in assuring the fulfillment of the rights enshrined in the 1988 Constitution (Taylor, 2008: 14).

Taylor uses two variables to explain the prominence achieved by Brazilian courts in the policy process under the current constitutional regime: judicial independence and judicial review (Taylor, 2008: 18). The first variable measures the degree of autonomy enjoyed by judges, and also their level of independence from other governmental actors (external independence) and from the hierarchy of the Judiciary branch (internal independence). The second variable considers what sorts of rights are constitutionally protected, which courts have what level of jurisdiction over disputes, the scope of judicial review and the rules of standing.

Considering the first variable, judicial independence, Taylor explains that judges in Brazil enjoy a high level of autonomy from other branches of government, and most of the times act without fear of retaliation. Also, judges are independent from external pressure and from internal direction from higher courts when deciding their cases. The fact that precedents have little binding effect except in very specific circumstances adds to that effect, allowing judges a great deal of liberty (Taylor, 2008: 44).

From the perspective of judicial review, the comprehensive set of legal rights contained in the 1988 Constitution affords citizens ample opportunities to resort to courts to voice their 
grievances and seek relief. Judges also have broad discretion when crafting their decisions, and are not bound by pre-established legal doctrines. Courts also have extremely favorable rules of standing (including at the Supreme Court level) (Taylor, 2008: 44-45).

All those characteristics of course affect the willingness of citizens to go to court when they feel wronged in their relationships with financial institutions. The ability to argue based on broad principles of law and constitutional protections, the high level of discretion and power that can be exercised by even the lowest ranking judges, and the guarantee of ample room for judicial review make courts a much more attractive venue than the hermetic environment of financial regulators.

\subsubsection{Legal Enforcement Shortcuts}

As described above, since 1999 the BCB has played an important role in advocating for institutional changes to increase creditor rights and speed up the enforcement of credit agreements. Many of the solutions proposed by BCB over the years created exceptions to general rules of private law that are applicable only to financial institutions. Two of the most telling examples are payroll debit loans and the broadening scope and applicability of fiduciary structures in credit transactions.

Payroll loans allow financial institutions to receive payments on their credit agreements directly from the employer of a customer, through an automatic payroll deduction. This structure significantly reduces the risk taken by the financial institutions because the customer relinquishes control over a part of his income from the get go, reducing information asymmetry and the administrative costs to receive payments (Fabiani, 2011: 76). Payroll loans were first introduced in Brazil in the early 1990s, but were initially restricted to public servants. This made the transaction almost risk-free for the banks, since public servants enjoy job stability. In 2003, President Silva enacted a Provisional Measure that became Law 10.820/03, extending payroll loans to private sector workers (Costa and Mello, 2009: 163).

The expansion of payroll loans of course generated disputes, and courts were initially reluctant to affirm payroll loan agreements. In a decision issued in June 2004, the Superior Court of Justice (Brazil's highest non-constitutional court) issued a decision affirming a regional court decision that had declared salary deduction as illegal (Costa and Mello, 2009: 163-164). 
The initial reaction by financial institutions and industry groups was of course negative, alerting to the risks of increased interest rates (Costa and Mello, 2009: 164). This did not stop payroll loans from growing in importance, and courts eventually accepted their validity. Nowadays, payroll loans represent 35\% of all credit transactions in Brazil (Costa and Mello, 2009: 161).

The increased use of fiduciary structures in credit transactions is another good example. Fiduciary structures in lending transactions allow creditors to retake their collateral in advance of bankruptcy procedures or through facilitated legal measures. Traditionally applicable to movable assets due to Law 4,728/65, the concept has been broadened through a series of legislative amendments to apply to shares (Law 6,404/76), immovable assets (Law 9,514/97), replaceable assets (Provisional Measure 2,160/01) and credit rights (Law 10,931/04) (Fabiani, 2011: 66-67). The changes made in the 2000s aimed exclusively at protecting transactions in financial and capital markets (Fabiani, 2011: 68-69).

Taking advantage of that concept, financial institutions have been granting credit and taking as collateral the fiduciary assignment of the debtor's receivable. In case the debtor files for a debt reorganization or goes bankrupt, the structure allows financial institutions to take possession of a debtor's receivables, which are excluded from the reorganization process or the bankruptcy estate. Faced with the prospects of debt reorganization or bankruptcy after entering into a fiduciary arrangement with banks, many debtors have recently sought relief in the Judiciary.

Debtors argue against the legality of the structure itself, and present policy reasons: the structure may effectively preclude the orderly recovery of the company because it allows banks to seize whatever revenue the company may still be able to obtain in the course of the procedures. ${ }^{41}$ Although there is still a high level of controversy, courts tend to recognize the legality of the structure (Salama, 2013a; Consultor Jurídico, 2013).

Regardless of the position that will eventually prevail in courts, the fact is that each time $\mathrm{BCB}$ or banks attempt to implement a new legal solution to increase creditor protection and speed up recovery, such solution is subject to judicial testing. Financial institutions also contribute to this "test tube" model by adopting what Salama calls "maximization drafting strategies", inserting protections of questionable legality in their agreements (Salama, 2012: 166) and proceeding to enforce them in a way that creates great legal

41 Djankov et al (2008: 1146-1147) argue that developing nations attempt to emulate developed ones and create sophisticated bankruptcy regimes that end up failing to save indebted companies an alarming $80 \%$ of the time. 
uncertainty to debtors as well (Silva et al, 2012: 23). ${ }^{42}$

As Falcão et al (2006) point out, by relying on such strategies, banks would effectively bear a part of the responsibility for such "judicial uncertainty". In fact, by shaping legal solutions based on untested arguments in their attempt to address specific issues, banks would create normative expectations which frustration would be a mere consequence of the normal routines of judicial decision-making, and not the product of "pathological uncertainty" (Falcão et al, 2006: 38-39 108-109).

In a context where citizens and non-industry interest groups have no available channel to meaningfully participate in conceiving or negotiating such solutions, and are also frequently ill-equipped to contribute or to understand their implications such behavior has particularly salient consequences (Hochstatler, 2012: 369): excluded actors are likely to find in courts their only way out of this legal conundrum. In this process of strategic institutional action and reaction, opportunities for increased litigiousness open up.

\section{Conclusion}

Current levels of litigiousness in Brazil are historically rooted, and cannot be traced solely to one event or set of events. As so, the explanation for why courts end up developing a role in existing conflicts is to be found in entrenched political, economic and legal structures that have crystallized during the past decades while the country successfully implemented a political transition to a democratic regime. Accordingly, the main ambition of this article is to formulate a narrative that identifies such structures and explains how they have come to shape, reinforce and sustain present levels of litigiousness.

In Brazil, the collapse of the military regime and the ensuing transition to democracy during the 1980s marks the embracement of two ideas - constitutionalism and economic regulation - that predictably undergo a difficult coexistence when incarnated in concrete arrangements.

42 The following excerpt from Silva et al (2012) describes how uncertainty around credit agreements affects debtors as well: "To the credit taker, uncertainty comes from various sources: (i) because the bank is able to take positions which are not described or insufficiently described in the initial agreement (additional fees, reciprocity demands); (ii) because the bank may make undue demands if the debtor faces payment difficulties; (iii) because the bank may deny credit renewal or set forth very unfavorable conditions for renewal; (iv) and, finally, because the credit taker has less knowledge of the real consequences of breaching the agreement" (Silva et al, 2012: 23). 
Such difficulty is remarkably well illustrated by the explosive levels of litigation that have now come to dominate Brazilian financial markets in general, and credit markets in particular. Brazilian citizens are currently at war with their banks, and courts have been transformed into the preferred battleground.

Taken together, the elements described in section 3 provide what we regard as a powerful institutional hypothesis to the question of why citizens primarily resort on courts to discuss the terms and conditions of their contractual relationship with financial institutions. As we note in the introduction to the previous section, it is worth to emphasize that each element cannot be understood or dealt with in isolation, but conform an institutional contexts that places a great burden in all involved parties, even financial institutions themselves. ${ }^{43}$

What we believe is the key lesson to draw from this paper is that high litigiousness in financial markets is an impediment to the full normalization of the Brazilian economy. The sheer volume of lawsuits pending before courts, the increase in delinquency rates and the characteristics of the Judiciary branch inevitably lead to inconsistent decisions, and some of them are bound to be debtor-friendly. But advocating for measures to increase creditor protection, shorten recovery times and fighting delinquency without considering macroeconomic factors is a narrow and incomplete way of addressing the problem (Oreiro et al, 2006: 631; Afonso et al, 2009: 32). ${ }^{44}$

Attributing high interest rates and high spreads to judicial uncertainty is also an incomplete explanation. It is of course true that litigation and judicial uncertainty leads financial institutions to demand higher risk compensation and in turn attract riskier customers. However, the whole process occurs in a much worse level because of the structural macroeconomic distortions that drive up interest rates in the first place, the opaque rulemaking procedures in financial regulation, and the other elements described above. But macroeconomic considerations are almost absent from the law and economics literature that has been driving policy reforms.

Eliminating the macroeconomic distortions that still prevent $\mathrm{BCB}$ from lowering interest

43 The extension of those costs to financial institutions themselves can be perceived by a recent announcement by $\mathrm{BB}$ of a decision not to appeal (or even to give up on already submitted appeals) of unfavorable decisions which are likely to be upheld by the Superior Court of Justice. This measure is part of a greater strategy to reduce the number of lawsuits in which BB is currently involved (850,000, the fight largest litigant before Brazilian courts), and to foster the use non-litigious dispute resolution methods with its clients (Consultor Jurídico, 2012). See, also, Aith (2009: 105-106)

44 Salama (forthcoming 2013b) offers a comprehensive examination of the reasons why macroeconomic considerations are almost absent from the law and economics literature in general. 
rates and making credit cheaper, opening up the regulatory process to wider public participation, increasing the role of $\mathrm{BCB}$ in consumer protection, implementing more effective regulatory instruments to allow for out-of-court resolution of disputes, focusing on legal reforms that are also mindful of debtor's rights, are all measures that that we believe would alleviate the litigious environment that currently prevails in financial markets.

The point we would like to end with is that reforming efforts will probably have a much greater change of bringing meaningful change if they address the background reasons that cause high litigiousness in financial markets, rather than merely attempting to make enforcement faster and easier. We also expect that our analytical focus will contribute to the identification of additional drivers of litigiousness in financial markets through future empirical research.

\section{References}

AFONSO, J. R.; KÖHLER, M. A.; FREITAS, P. S. Evolução e Determinantes do Spread Bancário no Brasil. Central de Estudos da Consultoria do Senado Federal - Texto para Discussão, No. 61, 2009.

AITH, M. O Impacto do Judiciário nas Atividades das Instituições Financeiras. IN: PINHEIRO, A. C. (Org.). Judiciário e Economia no Brasil, Editora Sumaré, p. 103-112, 2009.

ALESINA, A.; SUMMERS, L. H. Central Bank Independence and Macroeconomic Performance: some comparative evidence. Journal of Money, Credit and Banking, Vol. 25, No. 2, p. 151$162,1993$.

ALVES, S. D. S.; ALVES, T. M. S. A experiência brasileira de regulação: um caso de sucesso. In: GIAMBIAGI, F. (Org.) Risco e regulação: por que o Brasil enfrentou bem a crise financeira e como ela afetou a economia mundial. Rio de Janeiro: Campus, 2010, p. 171-188.

ARIDA, P.; BACHA, E. L.; LARA-RESENDE, A. Credit, Interest, and Jurisdictional Uncertainty: conjectures on the case of Brazil. In: GIAVAZZI, F.; GOLDFAJN, I.;

ARNONE, M.; LAURENS, B.J.; SEGALOTTO, J.F. The Measurement of Central Bank Autonomy: Survey of Models, Indicators, and Empirical Evidence. IMF Working Papers, No. WP/06/227, p. 1-85, 2006.

BAER, Werner. The Brazilian Economy: Growth and Development. Westport: Praeger Publishers, 5 ed., 2001

BARBOSA, N. Latin America: counter-cyclical policy in Brazil: 2008-09. Journal of Globalization and development, No. 1, 2010. 
BARRO, Robert. Determinants of Economic Growth - A cross-country empirical study. NBER Working Paper 5698, 1996.

BCB (Banco Central do Brasil). Economia Bancária e Crédito: avaliação de cinco anos do projeto juros e spread bancário, 2004.

Petição PGBC-2222/2010. Revista da Procuradoria-Geral do Banco Central, Vol. 4, No. 1, p. 289-311, 2010.

Relatório de Economia Bancária e Crédito, 2011.

Ranking de Bancos mais reclamados/ Abril de 2013. Available at: $<$ https://www3. bcb.gov.br/ranking/>

BERTRAN, Maria Paula. Interpretação Contratual e Análise Econômica do Direito: O Caso da Revisão dos Contratos de Leasing. São Paulo: Ed. Quartier Latin, 2008.

BIELSCHOWSKY, R. Estratégia de Desenvolvimento e as Três Frentes de Expansão no Brasil: um desenho conceitual. Economia e Sociedade, Vol. 21, Número Especial, p. 729-747, 2012.

CASTRO, M. F.; CARVALHO, M. I. V. Globalização e Transformações Políticas Recentes no Brasil: os anos 1990. Revista de Sociologia e Política, No. 18, p. 109-129, 2002.

CNJ (Conselho Nacional de Justiça). 100 Maiores Litigantes 2011. Brasília: CNJ, 2012. 100 Maiores Litigantes 2010. Brasília: CNJ, 2011.

COASE, R. The Problem of Social Cost. Journal of Law and Economics, Vol. 3, No. 1, p. $1-44,1960$.

COOTER, R; KORNHAUSER, L.; LANE, D. Liability Rules, Limited Information, and the Role of Precedent. Bell Journal of Economics, No.10, p. 366-373, 1979.

CONSIF (Confederação Nacional das Instituições Financeiras). CONSIF Protocola Ação no Supremo Tribunal Federal em Defesa da Constitutionalidade dos Planos Economômicos. Press Release, March 5, 2009.

CONSUltor JURÍDICO. BB Adota Política de Desistência de Ações Judiciais. November 7, 2012. Available at: <http://www.conjur.com.br/2012-nov-07/ banco-brasil-adota-politica-desistencia-acoes-judiciais $>$.

STJ Mantém Trava Bancária em Recuperação Judicial. February 17, 2013 (2013). Available at: <http://www.conjur.com.br/2013-fev-17/turma-stj-mantem-trava-bancaria-processo-recuperacao-judicial?goback $=\% 2 \mathrm{Eg}$ de_3865112_member_214923919>.

COSTA, A. C. A.; MELLO, J. M. P. Judicial Risk and Credit Market Performance: microevidence from Brazilian payroll loans. In: EDWARDS, S.; GARCIA, M. G. P (Orgs.). Financial Market Volatility and Performance in Emerging Markets, University of Chicago Press, p. 155-183, 2008. 
CROWE, C.; MEADE, E. E. Central Bank Independence and Transparency: evolution and effectiveness. IMF Working Papers, WP/08/119, p. 1-28, 2008.

DIEESE (Departamento Intersindical de Estatística e Estudos Econômicos). Spread e Juros Bancários. Nota Técnica No. 112, 2012.

DJANKOV, S. et al. Debt Enforcement Around the World. Journal of Political Economy, Vol. 116, No. 6, p. 1105-1149, 2008.

DUBASH, N. K.; MORGAN, B. Understanding the Rise of the Regulatory State of the South. Regulation \& Governance, No. 6, p. 261-281, 2012.

DURAN, C. V. O Supremo Tribunal Federal, os Planos Econômicos de Estabilização e a Construção da Moldura Jurídica do Poder Monetário. Revista da Procuradoria-Geral do Banco Central, Vol. 4, No. 1, p. 195-224, 2010.

DURAN-FERREIRA, C. V. O STF e a Construção Institucional das Autoridades Reguladoras do Sistema Financeiro: um estudo de caso das ADINs. Revista DireitoGV, Vol. 5, No. 1, p. 67-94, 2009.

FABIANI, E. R. Direito e Crédito Bancário no Brasil. São Paulo: Ed. Saraiva, 2011.

FACHADA, P.; FIGUEIREDO, L. F.; LUNDBERG, E. Sistema judicial e mercado de crédito no Brasil. Notas Técnicas do Banco Central do Brasil, No. 35, 2003.

FALCÃO, J.; SCHUARTZ, L. F.; ARGUELHES, D. W. Jurisdição, Incerteza e Estado de Direito. Revista de Direito Administrativo, No. 243, p. 79-112, 2006.

FRANCO, G. H.B. O desafio brasileiro: ensaios sobre desenvolvimento, globalização e moeda. São Paulo: Editora 34, 1996. 487, 2004.

Auge e declínio do inflacionismo no Brasil. Texto para Discussão- PUC Rio, No.

FREITAS, M. C. P. The Effect of the Global Crisis in Brazil: risk aversion and the preference liquidity in the credit market. Estudos Avançados, Vol. 23, No. 66, p. 125-145, 2009.

GONÇALVES, F. M.; HOLLAND, M.; SPACOV, A. D. Can Jurisdictional Uncertainty and Capital Controls Explain the High Level of Real Interest Rates in Brazil? Evidence from Panel Data. Revista Brasileira de Economia, Vol. 61, No. 1, p. 49-75, 2007.

GORDLEY, J. Equality in Exchange. California Law Review, Vol. 69, p. 1587-1656, 1981.

HALL, P. A.; SOSKICE, D. Introduction to Varieties of Capitalism. In: HALL, P. A.; SOSKICE, D. (Orgs), Varieties of Capitalism: the institutional foundations of comparative advantage. Oxford University Press, 2001.

HERRERA, S. Inflation Target, Debt and the Brazilian Experience, 1999-2003, Massachusetts Institute of Technology (MIT), 2005, p. 265-293. 
HOCHSTATLER, K. Civil Society and the Regulatory State of the South. Regulation \& Governance, No. 6 , p. 362-370, 2012.

IMF (International Monetary Fund). Brazil: Financial System Stability Assessment. IMF Country Report, No. 12/206, July, 2012.

JANTALIA, F. Juros Bancários. São Paulo: Ed. Atlas, 2012.

LA PORTA,R et al. Law and Finance. Journal of Political Economy, Vol. 106, No. 6 , p. 1113-1155, 1998.

LA PORTA, R.; LOPEZ-DE-SILANES, F.; SHLEIFER, A. The Economic Consequences of Legal Origins. Journal of Economic Literature, Vol. 46, No. 2 , p. 285-332, 2008.

LEVI-FAUR, D. The Global Diffusion of Regulatory Capitalism. Annals of the American Association of Political Science, No. 589, p. 12-32, 2005.

MANHIÇA, F. A.; JORGE, C. T. O Nível da Taxa Básica de Juros e o Spread Bancário no Brasil: uma análise de dados em painel. Texto para Discussão IPEA, No. 1710, 2012.

MELLO, J. M. P.; FUNCHAL, B.; COELHO, C.. The Brazilian Payroll Lending Experiment. The Review of Economics and Statistics, V. 94, p. 925-934, 2012.

MODENESI, André de Melo; MODENESI, Rui Lyrio. Quinze Anos de Rigidez Monetária no Brasil (1995-2008): uma agenda de pesquisa. In: ENCONTRO INTERNACIONAL DA ASSOCIAÇÃO KEYNESIANA BRASILEIRA, 3, UFRGS, 2010.

NERI, M. C. (coord.). A Nova Classe Média: o lado brilhante dos pobres. Rio de Janeiro: FGV/CPS, 2010.

NÓBREGA, M.F. O futuro chegou: instituições e desenvolvimento no Brasil. São Paulo: Editora Globo, 2005.

NOVAIS, L.F.; CAGNIN, R.F.. Retomada do Crescimento e Ciclo de Crédito no Contexto PósCrise: avanços e retrocessos. FUNDAP, Boletim de Economia No. 3, 2011.

OLIVEIRA, G. C.; CARVALHO, C. E. O Componente 'Custo de Oportunidade' do Spread Bancário no Brasil: uma abordagem pós-Keynesiana. Economia e Sociedade, Vol. 16, No. 3, p. 371-404, 2007.

OREIRO, J. L. C. et al. Determinantes Macroeconômicos do Spread Bancário no Brasil: teoria e evidência recente. Economia Aplicada, Vol. 10, No. 4, p. 609-634, 2006

PAIM, B. O Comportamento dos Créditos Público e Privado no Brasil, de 2004 a 2011. Indicadores Econômicos FEE, Vol. 40, No. 2, p. 33-44,2013.

PAULA, L. F.; LEAL, R. M. Custo do Crédito no Brasil: uma avaliação recente. Indicadores Econômicos FEE, Vol. 34, No. 2, p. 91-102, 2006. 
PALHARES, C. Evolução da Proteção Jurídica do Consumidor de Crédito no Brasil. In: LIMA, M.L.L.M.P. (Org), Direito e Economia: 30 Anos de Brasil. Vol. 2, São Paulo: Saraiva, p. $317-$ $365,2012$.

PEREIRA JÚNIOR, A.A. Legitimidade e Governabilidade na Regulação do Sistema Financeiro. Revista DireitoGV, Vol. 4, No. 2, p. 517-538, 2008.

PINHEIRO, A. C.; CABRAL, C. Mercado de Crédito no Brasil: o papel do Judiciário e outras instituições. Ensaios BNDES, No. 9, 1998.

PISTOR, K.; RAISER, M.; GELFER, S. Law and Finance in Transition Economies. Economics of Transition, Vol. 8, No. 2, p. 325-368, 2008.

PORTO, A. J. M. O Direito e a Economia do Cadastro Positivo. Revista de Direito Empresarial, No. 14 , p. 35-48, 2010.

POSNER, R. Economic Analysis of Law. New York: Aspen Law and Business, 6 ed., 2003.

. A Failure of Capitalism: The Crisis of ' 08 and the Descent into Depression. Harvard University Press, 2009.

PRADO, M. M. Interactions Between Courts and Agencies in Brazil. In: PRADO, M. M.; URUEÑA, Rene (Org..). Courts and the Regulatory State of the South: the case of Brazil (forthcoming).

PRADO, M. M.; URUEÑA, Rene. The Relevance of Courts in the Regulatory State of the South. 2013, Courts and the Regulatory State of the South: the case of Brazil (forthcoming).

PRIEST, G. The Common Law Process and the Selection of Efficient Rules. Journal of Legal Studies 6, p. 65-82, 1977.

RAPOSO, E.V.; KASAHARA, Y. Instituições Fortes, Moeda Estável e Banco Central do Brasil Autônomo. DADOS - Revista de Ciências Sociais, Vol. 53, No. 4, p. 921-958, 2010.

RIBEIRO, I. Robin Hood vs. King John Redistribution: how do local judges decide cases in Brazil? Available at SSRN 938174.

ROCHA, J. P. C. V. A capacidade normativa de conjuntura no direito econômico: o déficit democrático da regulação financeira. Tese (Doutorado em Direito)-Faculdade de Direito, Universidade de São Paulo, 2004.

RUBIN, P. Why is the Common Law Efficient? Journal of Legal Studies 6, p. 51-63, 1977.

SADDI, J. Crédito e judiciário no Brasil: uma análise de direito \& economia. São Paulo: Editora Quartier Latin, 2007.

SALAMA, B. M. Como interpretar as normas emitidas pelo Bacen e CMN? Uma resposta a partir da evolução do modelo de estado brasileiro. Revista de Direito Bancário e do Mercado de Capitais, No. 46, p. 103-128, 2009. 
. Regulação Cambial entre a Ilegalidade e a Arbitrariedade: o caso da compensação privada de créditos internacional. Revista de Direito Bancário e do Mercado de Capitais, $\mathrm{n}^{\circ}$ 50, p. 157-184. 2010a

Foreign Exchange Controls and the Governance of State Capitalism. Unpublished manuscript ,2013.

. Vetores da Jurisprudência na Interpretação dos Contratos Bancários no Brasil. Revista de Direito Bancário e do Mercado de Capitais, $n^{\circ}$ 57, 2012.

. Recuperação Judicial e Trava Bancária. Revista de Direito Bancário e do Mercado de Capitais, forthcoming, 2013a.

. The Art of Law \& Macroeconomics. University of Pittsburg Law Review, Vol. 74, No. 2, forthcoming, 2013b.

SANTOS, F.; PATRÍCIO, I. Moeda e Poder Legislativo no Brasil: Prestação de Contas de Bancos Centrais No Presidencialismo de Coalizão. Revista Brasileira de Ciências Sociais, Vol. 17, No. 49, p. 93-113, 2002.

SANTOS FILHO, Hermílio Pereira dos; TIMM, Luciano Benetti (coord.). Demandas Judiciais e Morosidade da Justiça Civil - Relatório Final Ajustado, 2011.

SCALON, C; SALATA. A. Uma Nova Classe Média no Brasil da Última Década? O debate a partir da perspectiva sociológica. Revista Sociedade e Estado, Vol. 27, No. 2, p. 387-407, 2012.

SEgURA-UBIERGO, A. The Puzzle of Brazil's High Interest Rates. International Monetary Fund, 2012.

SHLEIFER, A. The Failure of Judges and the Rise of Regulators. MIT Press, 2012.

SILVA, A. L. P.; YEUNG, L. L.-T.; CARVALHO, C. E. A Insegurança Jurídica Também é do Devedor: seleção adversa e custo do crédito no Brasil. In: LIMA, M.L.L.M.P. (Org), Direito e Economia: 30 Anos de Brasil. Vol. 2, São Paulo: Saraiva, p. 21-45, 2012.

SOBREIRA, R. The Brazilian Experience on Prudential Regulation and its Impacts on the 2008 Financial Crisis. Brazilian Journal of Political Economy, Vol. 31, No. 5 , p. 893-902, 2011.

SOLA, L.; KUGELMAS, E. Estabilidade Econômica e o Plano Real como Construção Política e Democratização - Statecraft, Liberalização Econômica. In: SOLA, L., KUGELMAS, E.; WHITEHEAD, L. (Orgs,), Banco Central, Autoridade Política e Democratização: Um Equilíbrio Delicado. Rio de Janeiro: Editora FGV, 2002.

SOUZA, S. R. S.; TABAK, B. M.; CAJUEIRO, D. O. Investigação da Memória de Longo Prazo da Taxa de Juros no Brasil. Revista Brasileira de Economia, Vol. 60, No. 2 , p. 193-209, 2006.

S\&P (Standard \& Poors). Ratings Direct, July 9, 2012 . 
TAYLOR, M. Judging Policy: Courts and Policy Reform in Democratic Brazil. Stanford University Press, 2008.

. Institutional Development Through Policy-Making: A Case Study of the Brazilian

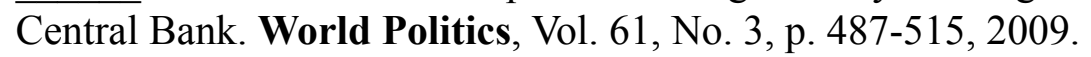

THIRUVENGADAM, A. K.; JOSHI, P. Judiciaries as Crucial Actors in Southern Regulatory Systems: a case study of Indian telecom regulation. Regulation \& Governance, No. 6, p. 327343, 2012.

TOLEDO, M. G. C. Avaliação da Crise: O sistema está sólido. In: GIAMBIAGI, F. Risco e regulação: por que o Brasil enfrentou bem a crise financeira e como ela afetou a economia mundial. Rio de Janeiro: Campus, 2010, pp. 223-237.

VALOR ECONÔMICO. Selic a 8\% Passa a Ser a Quarta Taxa de Juros Mais Alta do Mundo. May 29, 2013. Available at: <http://www.valor.com.br/financas/ 3143978/selic-8-passa-ser-quarta-taxa-de-juros-mais-alta-do-mundo>. 2013

VIANNA, L. W.; BURGOS, M. B. Entre Princípios e Regras: cinco estudos de caso de Ação Civil Pública. DADOS - Revista de Ciências Sociais, Vol. 48, No. 4, p. 777-843, 2005.

VIEIRA, O. V. Supremocracia. Revista Direito GV, No. 8, p. 441-463, 2008.

. Supremo Tribunal Federal: O Novo Poder Moderador. In: MOTA, C. G.; SALINAS, N. S. C. Os Juristas na Formação do Estado-Nação Brasileiro, São Paulo: Saraiva, 2010.

WALD, A. O Novo Direito Monetário: os planos econômicos, os contratos, o FGTS e a justiça. São Paulo: Malheiros Editores, 2002.

WSJ (Wall Street Journal). Banks Looking at \$100 Billion Legal Tab. March 27, 2013 . Available at: <http://online.wsj.com/article/SB1000142412788732346620 4578382261903001702.html. 2013 